\title{
Lockdown stress amid COVID-19 on Alcoholics and Drug addicts
}

\author{
Madona Mathew ${ }^{1 *}$
}

\section{ABSTRACT}

Alcohol consumption within the COVID-19 time may be a stress reliever. Loneliness and social distancing results in the increased use of alcohol. Alcohol consumption for endless period during the isolation has created new cases of disorders associated with alcohol use. Especially the increased risk of infection and deteriorating symptoms. Citizens should be properly trained about alcohol-related problems during this emergency period. The Coronavirus Disease pandemic has undoubtedly had a serious impact on the supply of physical healthcare worldwide. The psychological state impact of this pandemic can't be underestimated, particularly of patients affected by addiction. Heightened public stress and anxiety levels, increasing isolation and therefore the physical consequences of addiction play an outsized role within the proliferation and ongoing relapse of substance misuse and behavioural addiction.

Keywords: Addiction, Drugs, Covid-19, Alcoholic, Stress

$\mathbf{S}$ oon after Prime Minister Narendra Modi announced the 21-day lockdown last week to contain the spread of the coronavirus pandemic, many wondered, perhaps in a jocular vein, how smokers, alcoholics or people addicted to drugs would cope with new regimen

According to some media reports, by March 30, Kerala had registered eight cases of suicide by individuals, who failed to cope with alcohol withdrawal. The official death toll from the coronavirus infection in Kerala, so far, stands at two. Perhaps wary of having to deal with an epidemic of alcohol addiction-related suicides while the state continues to battle the Covid19 pandemic, the Pinarayi Vijayan government allowed people unable to cope with withdrawal to purchase liquor from government-notified vends if a doctor prescribed the amber stuff to them. The Kerala government's decision has been met with stiff resistance from state's Indian Medical Association (IMA) chapter which wrote to the CM stating "alcohol withdrawal can be managed successfully using medications" and that "asking doctors to recommend alcohol as treatment of alcohol withdrawal would be sending a wrong message to the public". Nonetheless, the Meghalaya government, too, followed Kerala's lead, allowing alcohol to be sold to people who came armed with a doctor's prescription.

\footnotetext{
${ }^{1}$ Student, M.Sc. Forensic Science, Raksha Shakti University, Gujarat, India *Responding Author
}

Received: June 13, 2020; Revision Received: June 22, 2020; Accepted: September 25, 2020

(C) 2020, M Mathew; licensee IJIP. This is an Open Access Research distributed under the terms of the Creative Commons Attribution License (www.creativecommons.org/licenses/by/2.0), which permits unrestricted use, distribution, and reproduction in any Medium, provided the original work is properly cited. 
As India enters into the second week of the lockdown, and amid uncertainty over whether this quarantine would end on April 15 or be extended, addiction psychiatrists believe the going may get tough for "severe addicts" of alcohol, illicit drugs and psychotropic substances and also for those presently under rehab.

\section{DISCUSSION}

As Coronavirus spreads rapidly across the world, lockdown is the new normal life for many people, given that the usual rules of life have changed, which has led to a surge in a danger as profound as the virus - domestic violence. To curtail the spread of COVID-19, governments across the world have imposed lockdowns and implored residents to stay home; the only way protect themselves and others from the new Coronavirus disease, COVID-19, but those same restrictions have increased the risks associated with domestic violence, especially for women and children.

At the same time, fears around loss of jobs and financial stress are increasing the likelihood of violent conflicts at home. This is even as experts have characterised an "invisible pandemic" of domestic violence during the COVID-19 crisis as a "ticking time bomb" or a "perfect storm," being that growing unemployment, increased anxiety and financial stress, rising numbers of sick people, and a scarcity of community resources have set the stage for an exacerbated domestic violence crisis.

"Many victims now find themselves isolated in violent homes, without access to resources or friend and family networks. Abusers could experience heightened financial pressures and stress, increase their consumption of alcohol or drugs, and purchase or hoard guns as an emergency measure,".

\section{Addiction amid lockdown}

In an effort to regulate the COVID-19 pandemic, governments of various countries have implemented social distancing, resultingin many people being isolated for long periods. Alcohol misuse is one among the leading causes of preventable mortality, contributing annually to about 3 million deaths worldwide. In some individuals, long term, excessive alcohol misuse might escalate into an alcohol use disorder. The potential public health effects of long-term isolation on alcohol use and misuseare unknown. Stress may be a prominent risk factor for the onset and maintenance of alcohol misuse. Chronic alcohol use leads to neuroadaptations in stress and reward pathways, which cause dysfunctional hypothalamic pituitary adrenocortical and sympathetic adrenomedullary axes, characterised by dysregulation of the cortisol response and deficits in emotional regulation. In turn, these neuro adaptations cause increased cravings for alcohol in response to worry.

We have heard this over and over within the previous couple of months - there may be a lockdown and other people are forced to remain indoors, that's if they need to urge out of this alive. Coronavirus has brought the whole world to a standstill affecting normal life. While a couple of sectors have asked its employees to figure from home, youngsters are having an excellent time binge-watching Netflix and playing games. On the opposite hand, there are celebrities who have literally spammed their instagram with workout videos and pictures of them doing household chores for the primary time. Environmentalists and nature lovers are the happiest sharing pictures of deer who just walked out of the wild to laze around on a road which might otherwise been crammed with vehicles with no place for even pedestrians to steer. Anyway, while the planet is moving on, although at a snail's pace, there's another section of individuals who are finding it difficult to handle this lockdown. 
We know that the majority parts of the planet have shut stores and stopped supply of alcohol. In countries like India, it's completely dry, which suggests access to alcohol is next to impossible unless you've got stocked up earlier itself otherwise you have a bar reception.

\section{Withdrawal Symptoms}

Bouts of headaches, vomiting, body ache, loss of appetite and sleeplessness are only few of the various withdrawal symptoms an individual trying to urge obviate a habit goes through. abandoning a habit must be planned and wishes ample time. Moreover, social distancing for the fear of contracting the corona viral infection has not made life any easier. most of the people who use drugs or consume alcohol are wont to a group which minimise the impact it's on his/her psychological state. Now, with even meetings being stop, it's as if their lifeline is broken and people seeking counselling from psychiatrists for psychological state too are finding it difficult with online sessions not providing them the comfort they got during a face-to-face therapy. If you thought that creating addicts abstain from substance use or alcohol would help them hand over their habit altogether, then it is a big illusion.

Two young men in Kerala committed suicide after being frustrated over not having the ability to seek out alcohol thanks to the coronavirus lockdown. In Karnataka, there have been two more similar cases of suicide over an equivalent reason. it's a known incontrovertible fact that including drug abuse and alcoholism, even kicking the butt (cigarettes) is not any easy feat to realize. It requires tons of will power and doesn't happen overnight just because those affected by addiction any of those face withdrawal symptoms.

Withdrawal symptoms overpower them and there are far reaching consequences considering how fragile their body and mind is. Isolation or quarantine for these people just doesn't work, the govt must found out a committee of experts and psychological state specialists to return up with a possible solution to keeping these people sane till the top of the lockdown period because besides the coronavirus, these people have their own battles too.

\section{CONCLUSION}

Addiction has a significant impact on the spread of COVID-19, as well as its progression. When individuals abuse substances, especially alcohol, their decision-making and judgement are often impaired, as is their ability to properly gauge risk. For this reason, they may not follow social distancing guidelines and contribute to the spread of the virus.

Men, especially in countries like Italy and China, have a significantly higher rates of hospitalization and fatality than women. However, it appears that men and women are infected at roughly equal rates. It has been widely theorized that one of the primary factors at play is that men demonstrate significantly higher rates of smoking than women in these countries. It is believed that the long-term long and respiratory damage caused by smoking weakens them and leaves them especially vulnerable to COVID-19/Coronavirus. It is unclear whether this applies to other smoked drugs such as Crack Cocaine, Marijuana, and Meth, but it is very likely. Additionally, intravenous drug use, such as shooting Heroin or other opioids, is known to dramatically increase the risk of heart and other pulmonary infections, which also make an individual more susceptible to the worst consequences of COVID-19-Coronavirus. 


\section{REFERENCES}

Da Silva, J., \& Testino, G. Risks of alcohol abuse, alcoholism and stress-related drinking during the COVID-19 pandemic. Alcoholism and Drug Addiction/Alkoholizm i Narkomania, 32(1).

Tresler-Ulriksen, M. (2009). Lockdown: are teens (and taxpayers) paying the price at christian reform schools? The Humanist, 69(3), 10.

COVID-19 Dashboard by the Center for Systems Science and Engineering (CSSE) at Johns Hopkins University (JHU). https://coronavirus.jhu.edu/map.html (Accessed:20.05.2020).

Clay JM, Parker MO. Alcohol use and misuse during the COVID-19 pandemic: a potential public health crisis? Lancet Public Health 2020; 5(5): E259. doi: 10.1016/S24682667(20)30088-8.

World Health Organization. Alcohol and COVID-19: what you need to know. http://www.euro.who.int/_data/assets/pdf_file/0010/437608/Alcohol-and-COVID19-what-you-need-to-know.pdf (Accessed: 20.05.2020).

\section{Acknowledgements}

The author appreciates all those who participated in the study and helped to facilitate the research process.

\section{Conflict of Interest}

The author declared no conflict of interest.

How to cite this article: M Mathew (2020). Lockdown stress amid COVID-19 on Alcoholics and Drug addicts. International Journal of Indian Psychology, 8(3), 13-16. DIP:18.01.002/20200803, DOI:10.25215/0803.002 